\title{
Pengaruh gaya kepemimpinan kepala sekolah terhadap kinerja guru di SMK Negeri 11 Bandung
}

(The influence of the principal's leadership style on the performance of teachers in the vocational school of 11 Bandung)

\author{
Aissah Qomaria Azis', Suwatno ${ }^{2 *}$ \\ 1,2Program Studi Pendidikan Manajemen Perkantoran, \\ Fakultas Pendidikan Ekonomi dan Bisnis, Universitas Pendidikan Indonesia \\ Jl. Dr. Setiabudhi, No. 229 Bandung, Jawa Barat Indonesia \\ Email: suwatno@upi.edu
}

\begin{abstract}
ABSTRAK
Tulisan ini mengkaji secara khusus tentang gaya kepemimpinan kepala sekolah sebagai faktor yang diduga kuat mempengaruhi kinerja guru. Berdasarkan hasil analisis data dengan menggunakan analisis regresi sederhana dan menggunakan metode explanatory survey sebagai alat pengumpulan data serta menggunakan angket jawaban terhadap 66 orang responden yang merupakan guru tetap di Sekolah Menengah Kejuruan Negeri 11 Bandung. Hasil analisis tersebut menunjukan bahwa gaya kepemimpinan kepala sekolah memiliki pengaruh terhadap kinerja guru. Hasil penelitian ini menunjukan gaya kepemimpinan memiliki pengaruh positif dan signifikan terhadap kinerja guru.
\end{abstract}

Kata kunci: Gaya Kepemimpinan Kepala Sekolah; Kinerja Guru

\begin{abstract}
This paper examines specifically about the principal's leadership style as a factor that allegedly affect the performance of teachers. Based on the analysis of data using simple regression analysis and using explanatory survey method as a means of collecting data and using the questionnaire answers to the 66 respondents who are permanent teachers at State Vocational High School 11 Bandung. Results of the analysis showed that the principal's leadership style had an influence on the performance of teachers. These results indicate leadership style has a positive and significant impact on teacher performance.
\end{abstract}

Keywords: Principal's Leadership Style;Performance of Teachers

\section{PENDAHULUAN}

Berdasarkan Peraturan Menteri Negara Pendayagunaan Aparatur Negara Dan Reformasi Birokrasi Republik Indonesia No. 16 Tahun 2009 guru merupakan seorang pendidik professional dengan tugas utama mendidik, mengajar, membimbing, mengarahkan, melatih, menilai dan mengevaluasi peserta didik pada pendidikan anak usia dini, jalur pendidikan formal, pendidikan dasar dan pendidikan menengah. Sebagai

Received: Februari 2019, Revision: Mei 2019, Published: Juli 2019

\footnotetext{
*Corresponding author

Copyright (C 2019, EISSN 2656- 4734
} 
seorang pendidik yang professional, maka sudah seharusnya apabila diadakan pengembangan keprofesionalan guna mengembangkan kompetensi guru yang dilaksanakan sesuai dengan kebutuhan, bertahap dan berkelanjuta atau yang sering di sebut sebagai penilaian kinerja. Hamzah B. Uno (2012, hal. 93) mengungkapkan bahwa kinerja guru merupakan gambaran hasil kerja yang dilakukan pendidik terkait dengan tugas yang diembannya dan merupakan tanggung jawabnya.

Rekapitulasi rata-rata angka penilaian kinerja guru di SMK Negeri 11 Bandung mengalami peningkatan, dari tahun 2015 berada pada angka 59.60\% meningkat pada tahun 2016 menjadi $69.69 \%$ dan secara keseluruhan angkat tersebut mengindikasikan bahwa kinerja guru di sekolah tersebut berpredikat baik.

Salah satu bahan penilaian kinerja guru adalah kemampuan guru dalam melakukan kegiatan di kelas yang akan tercermin dari hasil belajar yang didapat oleh peserta didik. Dari data yang diperoleh, sebanyak 89\% atau sebanyak 331 orang siswa kelas $\mathrm{X}$ dari jumlah siswa sebanyak 371 orang siswa memiliki nilai yang tidak memenuhi nilai Kriteria Ketuntasan Minimal (KKM) pada mata pelajaran matematika. Sedangkan untuk kelas XI terdapat $81 \%$ atau 308 orang siswa yang belum memenuhi nilai Kriteria Ketuntasan Minimal (KKM) pada mata pelajaran yang sama. Mata pelajaran Bahasa Mandarin merupakan mata pelajaran yang memiliki nilai ketidak tuntasan paling sedikit untuk siswa kelas X, yaitu sebanyak 69 orang siswa atau $19 \%$. Berbeda dengan kelas XI, mata pelajaran sejara merupakan mata pelajaran yang paling sedikit memiliki siswa yang tidak memenuhi KKM, yaitu sebanyak 59 orang siswa atau sebanyak $16 \%$.

Fenomena di atas menunjukan bahwa kegiatan belajar mengajar yang dilakukan belum efektif. Hal ini tidak sesuai dengan penilaian kinerja guru di SMK Negeri 11 Bandung Periode 2016/2017 yang menunjukan bahwa guru di SMK Negeri 11 Bandung memiliki peringkat rata-rata kinerja sebesar $69.69 \%$ yang dapat diartikan bahwa para guru memiliki kinerja "CUKUP BAIK".

Salah satu faktor yang dapat mempengaruhi dan mendukung kinerja seorang guru adalah kemampuan manajerial yang dimiliki oleh pimpinan. Kemampuan ini bertujuan agar kepala sekolah dapat mempengaruhi para guru sebagai bawahannya untuk dapat mencapai tujuan organisasi yang telah diputuskan bersama.

Secara khusus penelitian ini mempertanyakan faktor yang dapat mempengaruhi kinerja seoranag guru dengan melakukan pembatasan variabel yaitu kepemimpinan, atau dalam penelitian ini adalah gaya kepemimpinan dan seberapa besar pengaruh dari gaya kepemimpinan tersebut terhadap kinerja yang dimiliki oleh guru.

\section{TINJAUAN PUSTAKA}

Pembahasan mengenai keterkaitan antara variabel, perlu dibahas juga secara komperhensif pada setiap konsep yang terkait, dalam hal ini yaitu gaua kepemimpinan kepala sekolah dan kinerja guru.

\section{GAYA KEPEMIMPINAN KEPALA SEKOLAH}

Gaya kepemimpinan berasal dari dua suku kata yaitu gaya dan kepemimpinan. Dalam bukunya, Sedarmayanti (2010, hal. 130) berpendapat bahwa gaya adalah sikap, gerakan, tingkah laku, sikap yang elok, gerak-gerik yang bagus, kekuatan, kesanggupan untuk berbuat baik. Masalah kepemimpinan telah muncul bersamaan dengan dimulainya sejarah manusia, yaitu sejak menyadari pentingnya hidup berkelompok untuk mencapai tujuan bersama. Mereka membutuhkan seseorang atau beberapa orang 
yang mempunyai kelebihan dibandingkan yang lainnya. John Adair dalam Susanto \& Aisiyah (2010, hal. 19) menyatakan bahwa seorang pemimpinan adalah seseorang yang memiliki keperibadian dan watak tertentu yang sesuai dengan situasi umum, didukung dengan kemampuan teknis dan pengalaman yang relevan, yang diperlukan untuk menuntun kelompok mencapai tujuan dan dalam waktu yang bersamaan memelihara dan membangun persatuan tim.

Stephen P. Robbins (2013, hal. 368) mendefinisikan bahwa kepemimpinan sebagi "The ability to influence a group toward the achievment of goals" (Seorang pemimpin dituntut memiliki kemampuan untuk dapat mempengaruhi orang lain, mempunyai orang atau tim yang dipimpin, serta adanya pencapaian tujuan secara keseluruhan). Sedangkan mengenai kepemimpinan, Nogi (2005, hal. 203) berpendapat bahwa suatu organisasi akan berhasil atau bahkan gagal, sebagian besar ditentukan oleh kepemimpinan yang ada.

Secara berurutan, penelitian dan teori kepemimpinan dapat diklasifikasikan dalam pendekatan sifat, perilaku dan situasional-contingency. Dalam penelitian ini, pendekatan yang digunakan adalah pendekatan perilaki yang dimana pendekatan perilaku membahas mengenai beberapa perilaku yang efektif dilakukan oleh pemimpin dalam menjalankan kepemimpinannya, perilaku pemimpi bisa dipelajari sehingga bisa dibentuk dengan pembiasaan yang disengaja. Pendekatan perilaku mengantarkan kita pada suatu anggapan bahwa pemimpin itu dibentuk bukan dilahirkan. Dalam pendekatan perilaku terdapa beberapa teori kepemimpinan, teori yang penulis gunakan adalah teori Path-Goal Evan-House.

Teori yang dirumuskan oleh Martin G. Evans dan Robert J. House ini mencoba membantu untuk dapat memahami dan meramalkan efektivitas kepemimpinan dalam situasi yang berbeda (Wahjono, 2010, hal. 283-284). Teori ini menekankan bahwa motivasi seseorang tergantung dari harapannya akan imbalan dan valensi, atau daya tarik imbalan itu. Manajer harus dapat memberikan imbalan atau stimulus dan menjelaskan apa yang harus dilakukan oleh bawahan untuk memperolehnya. EvansHouse mengidentifikasi tiga gaya kepemimpinan untuk menjelaskan teorinya, yaitu:

a. Gaya kepemimpinan direktif. Tipe ini sama dengan model kepemimpinan otokratik dari Lippit dan White. Bawahan tahu senyatanya apa yang diharapkan darinya dan pengarahan yang khusus diberikan oleh pemimpin. Dalam model ini tidak ada partisipasi bawahan karena pemimpin mengarahkan tentang apa yang harus dilakukan dan bagaimana caranya, menjadwalkan pekerjaan, mempertahankan standar kinerja, hal ini memperjelas peranan pemimpin yang sangat otoriter mengatur kelompoknya.

b. Gaya kepemimpinan yang mendukung (Supportive leadership). Kepemimpinan model ini mempunyai kesediaan untuk menjelaskan sendiri, bersahabat, mudah didekati, dan mempunyai perhatian kemanusiaan yang murni terhadap para bawahannya. Pemimpin yang menggunakan gaya ini melakukan berbagai usaha agar pekerjaan menjadi lebih menyenangkan, memperlakukan anggota dengan adil, bersahabat, dan mudah bergaul, memperhatikan kesejahteraan bawahannya.

c. Gaya Kepemimpinan partisipasif. Dalam gaya kepemimpinan ini pemimpin berusaha meminta dan mempergunakan saran-saran dari para bawahannya. Namun pengambilan keputusan masih tetap berada padanya. 


\section{The Path-Goal Theory}

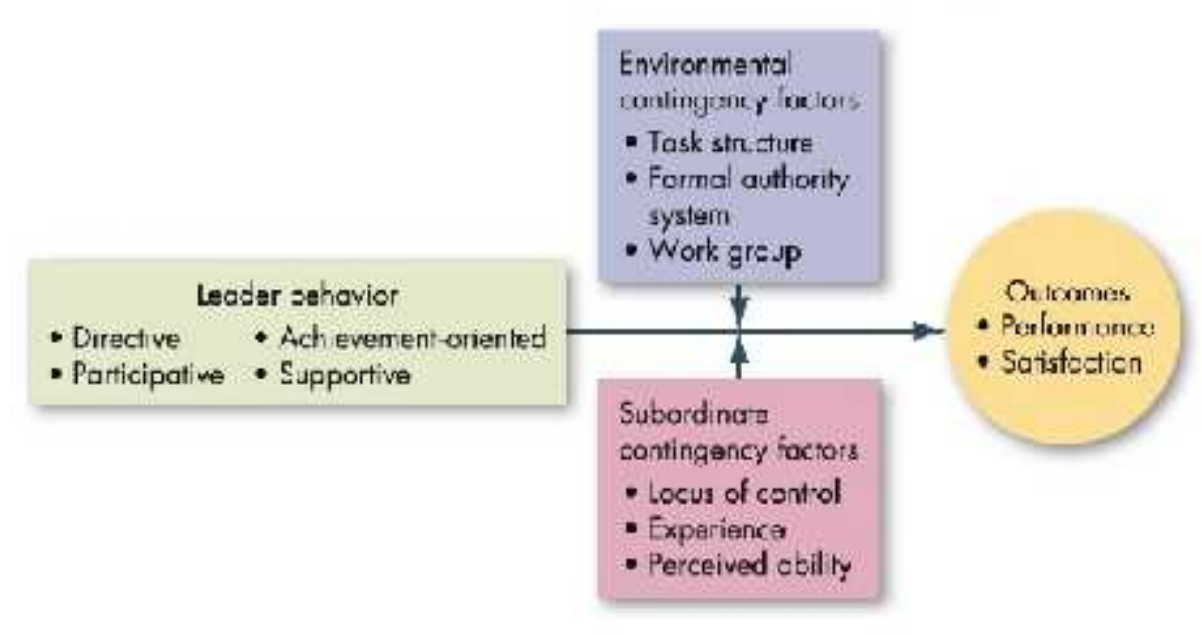

Gambar 1

Teori Gaya Kepemimpinan Path-Goal

\section{KINERJA GURU}

Menurut Byars dan Rue (dalam Susanto, 2012 hal. 200) "Performance refers to degree of accomplishment of the tasks that make up an individual's job. It reflect how well an individual is fulfilling the requirements of a job". Pendapat Byars dan Rue diartikan bahwa kinerja atau performance mengacu pada derajat tingkat penyelesaian tugas yang melengkapi pekerjaan seseorang. Hal ini mencerminkan seberapa baik seseorang dalam melaksanakan tuntutan suatu pekerjaan. Suwatno (2009, hal. 265) berpendapat bahwa kinerja guru secara operasional dapat didefinisikan sebagai kualitas dan kuantitas dalam memgajar berdasarkan kompetensi yang dimilikinya.

Hamzah B. Uno (2012, hal. 93) mengungkapkan bahwa kinerja guru merupakan gambaran hasil kerja yang dilakukan pendidik terkait dengan tugas yang diembannya dan merupakan tanggung jawabnya. Sedangkan pengertian kinerja guru menurut Peraturan Menteri Pendidikan Nasional Nomor 35 Tahun 2010 adalah proses dan hasil kerja yang dicapai guru dalam melaksanakan tugasnya yang meliputi merencanakan, melaksanakan dan menilai hasil pembelajaran, membimbing dan melatih peserta didik

Terdapat banyak pendapat yang mengemukakan mengenai faktor yang dapat mempengaruhi kinerja, salah satunya adalah Mulyasa. Menurut Mulyasa (2003, hal. 140), faktor-faktor yang mempengaruhi kinerja sorang guru antara lain:

1) Sikap mental berupa motivasi, disiplin dan etika kerja.

2) Tingkat pendidikan, pada umumnya orang yang mempunyai pendidikan lebih tinggi akan mempunyai wawasan yang lebih luas.

3) Keterampilan, makin terampil tenaga kependidikan akan lebih mampu bekerja sama serta menggunakan fasilitas dengan baik.

4) Manajemen atau gaya kepemimpinan kepala sekolah, artinya sama dengan hal yang berkaitan dengan sistem yang diterapkan oleh pimpinan untuk mengelola dan memimpin serta mengendalikan tenaga pendidikan. 
5) Hubungan industrial, menciptakan ketenangan kerja dan memberikan motivasi kerja, menciptakan hubungan kerja yang serasi dan dinamis dalam bekerja dan meningkatkan harkat dan martabat tenaga kependidikan sehingga mendorong mewujudkan jiwa yang berdedikasi dalam upaya peningkatan kinerjanya.

6) Tingkat penghasilan atau gaji yang memadai, ini dapat menimbulkan konsentrasi kerja dan kemampuan yang dimiliki dapat dimanfaatkan untuk meningkatkan kinerjanya.

7) Kesehatan, akan meningkatkan semangat kerja.

8) Jaminan sosial yang diberikan dinas pendidikan kepada tenaga pendidik dimaksudkan untuk meningkatkan pengabdian dan semangat kerjanya.

9) Lingkungan sosial dan suasana kerja yang baik akan mendorong tenaga kerja kependidikan dengan senang bekerja dan meningkatkan tanggung jawabnya untuk melakukan pekerjaan yang lebih baik.

10) Kualitas sarana pembelajaran, akan menunjang kegiatan pembelajaran dan berpengaruh pada peningkatkan kinerja guru dalam proses belajar mengajar.

\section{PENGARUH GAYA KEPEMIMPINAN KEPALA SEKOLAH TERHADAP KINERJA GURU}

Kinerja merupakan keluaran yang dihasilkan oleh fungsi-fungsi atau profesi yang dilaksanakan oleh sumber daya manusia atau pegawai dalam waktu tertentu. Kinerja merupakan salah satu variabel dependen yang berhubungan langsung dengan kepemimpinan atau melalui variabel antara atau mediasi. Banyak faktor yang mempengaruhi kinerja, salah satunya adalah kepemimpinan.

Menurut Simamora (dalam Wardana, 2013, hal. 102), kinerja (performance) dipengaruhi oleh tiga faktor, yaitu faktor individual yang terdiri dari (1) kemampuan dan keahlian, (2) latar belakang, dan (3) demografi. Faktor psikologis yang terdiri dari (1) persepsi, (2) attitude, (3) personality, (4) pembelajaran dan (5) motivasi. Faktor organisasi yang terdiri dari (1) kepemimpinan, (2) penghargaan, (3) struktur dan (4) Job design.

Pendapat lain dikemukakan oleh Sedarmayanti (2001, hal. 89) kinerja merupakan kemampuan dan keberhasilan guru dalam melaksanakan tugas-tugas pemberlajaran. Kinerja guru dipengaruhi oleh berbagai faktor. Faktor-faktor yang mempengaruhi kinerja tersebut antara lain; (1) Sikap mental (Motivasi kerja, disiplin kerja dan etika kerja), (2) Pendidikan, (3) Keterampilan, (4) Kepemimpinan, (5) Tingkat penghasilan, (6) Gaji dan kesehatan, (7) Jaminan sosial, (8) Iklim kerja, (9) Fasilitas, (10) Teknologi, dan (11) Kesempatan berprestasi

Berdasarkan pada tinjuan pustaka yang sudah dibahas maka kerangka pemikiran dalam penelitian ini adalah sebagai berikut:

Gaya Kopemimpinan Kepala Sekolah

\section{Kinerja Guru}

Gambar 2.

Theoritical Framework 


\section{METODOLOGI}

Penelitian ini dilakukan dengan menggunakan metode deskriptif. Teknik pengumpulan data yang digunakan adalah dengan pengumpulan angket yang menggunakan model skala likert. Responden pada penelitian ini adalah para guru tetap di Sekolah Menengah Kejuruan (SMK) Negeri 11 Bandung yang berjumlah 66 orang. Teknik analisis data yang digunakan adalah analisis regresi sederhana dan korelasi product moment.

Instrumen penelitian berupa angket tersebut terdiri atas dua bagian yaitu angket untuk mengukur gaya kepemimpinan kepala sekolah yang terdiri dari tiga indikator, diantaranya gaya kepemimpinan direktif, gaya kepemimpinan suportif dan gaya kepemimpinan partisipatif. Sedangkan untuk mengukur kinerja guru terdiri dari empat indikator, diantaranya kompetensi pedagogik, kompetensi professional, kompetensi sosial dan kompetensi kepribadian.

Berdasarkan pendahuluan dan tinjauan pustaka, penelitian ini bertujuan untuk mengetahui gambaran gaya kepemimpinan kepala sekolah dan kinerja guru menggunakan statistik deskriptif. Selanjutnya berdasarkan pendahuluan dan tinjauan pustaka dapat dikembangkan menjadi sebuah hipotesis penelitian yaitu terdapat pengaruh gaya kepemimpinan kepala sekolah terhadap kinerja guru, yang kemudian akan diuji dengan menggunakan statistik inferensial dengan formula statistik regresi sederhana.

\section{HASIL PENELITIAN}

\section{Gaya kepemimpinan kepala sekolah sebagai Determinan kinerja guru}

Berdasarkan hasil pengolahan data dari jawaban angket responden, gambaran persepsi responden mengenai gaya kepemimpinan kepala sekolah di SMK Negeri 11 Bandung berada pada kategori kuat dengan kecenderungan responden menjawab alternatif jawaban setuju sebanyak $46 \%$.

Tabel 1.

Kecenderungan Jawaban Responden terhadap Variabel Gaya Kepemimpinan Kepala Sekolah

\begin{tabular}{|c|c|c|c|}
\hline Tingkatan & Frekuensi & Presentase & Kategori \\
\hline Sangat Tidak Setuju & 6 & $0 \%$ & Tidak Baik \\
\hline Tidak Setuju & 133 & $11 \%$ & Kurang Baik \\
\hline Setuju & 574 & $46 \%$ & Baik \\
\hline Sangat Setuju & 541 & $43 \%$ & Sangat Baik \\
\hline Jumlah & $\mathbf{1 2 5 4}$ & $\mathbf{1 0 0 \%}$ & \\
\hline
\end{tabular}

Sumber: Hasil Pengolahan Data

Selanjutnya mengenai gambaran persepsi kinerja guru berada pada kategori kuat dengan kecenderungan responden menjawab alternatif jawaban setuju sebanyak $47 \%$. 
Tabel 2

Kecenderungan Jawaban Responden terhadap Variabel Kinerja Guru

\begin{tabular}{|c|c|c|c|}
\hline Tingkatan & Frekuensi & Presentase & Kategori \\
\hline Sangat Tidak Setuju & 3 & $0 \%$ & Sangat Rendah \\
\hline Tidak Setuju & 122 & $10 \%$ & Rendah \\
\hline Setuju & 556 & $47 \%$ & Tinggi \\
\hline Sangat Setuju & 507 & $43 \%$ & Sangat Tinggi \\
\hline Jumlah & $\mathbf{1 1 8 8}$ & $\mathbf{1 0 0 \%}$ & \\
\hline
\end{tabular}

Sumber: Hasil Pengolahan Data

Teknik analisis data yang digunakan dalam penelitian ini adalah regresi sederhana dengan uji $\mathrm{F}$. Kriteria pengujian hipotesis yaitu Jika $\mathrm{H}_{0}$ ditolak dan $\mathrm{H}_{1}$ diterima, apabila $\mathrm{F}_{\text {hitung }}>\mathrm{F}_{\text {tabel, }}$ maka dinyatakan signifikan (diterima). Jika $\mathrm{H}_{0}$ ditolak dan $\mathrm{H}_{1}$ ditolak, apabila $\mathrm{F}_{\text {hitung }}>\mathrm{F}_{\text {tabel }}$, maka dinyatakan tidak signifikan (ditolak).

Hasil pengolahan data statistic didapatkan persamaan regresi $y=288.66 \%+0.374 x$. Persamaan tersebut mengandung makna bahwa keduanya berjalan searah, artinya jika gaya kepemimpinan kepala sekolah baik, maka kinerja guru akan meningkat. Nilai $F_{\text {hitung }}$ sebesar 12.789 sedangkan $F_{\text {tabel }}$ dengan tingkat kesalahan $\alpha$ $=0.05$ dan $\mathrm{db} 1=\mathrm{k}$, dan $\mathrm{db} 2=\mathrm{n}-\mathrm{k}-1$ yaitu $\mathrm{F}_{(0.05 ; 1,64)}=-3.991$, artinya $\mathrm{F}_{\text {hitung }}>\mathrm{F}_{\text {tabel }}$ yaitu $12.798>-3.991$, maka $\mathrm{H}_{0}$ ditolak dan $\mathrm{H}_{1}$ diterima. Sehingga dapat disimpulkan bahwa terdapat pengaruh yang positif dan signifikan antara gaya kepemimpinan kepala sekolah dan kinerja guru.

Besarnya hubungan Antara variabel gaya kepemimpinan kepala sekolah dengan kinerja guru dapat dihitung dengan menggunakan korelasi product moment hasilnya sebesar 0.408. Artinya hubungan Antara variabel gaya kepemimpinan kepala sekolah dengan kinerja guru memiliki hubungan yang cukup baik atau sedang. Koefisien determinasi variabel gaya kepemimpinan kepala sekolah terjadap kinerja guru yaitu sebesar 17\%. Hal ini menunjukan bahwa kinerja guru dipengaruhi oleh gaya kepemimpinan sebesar $17 \%$ dan sisanya sebesar $83 \%$ dipengaruhi oleh faktor lain.

\section{KESIMPULAN}

Gaya kepemimpinan kepala sekolah merupakan salah satu faktor yang mempengaruhi kinerja guru. dengan demikian, setiap peningkatan kualitas gaya kepemimpinan kepala sekolah, maka kinerja guru juga akan meningkat. Hasil penelitian ini menunjukan bahwa gaya kepemimpinan kepala sekolah berpengaruh terhadap kinerja guru. hal ini menjadi perhatian bagi sekolah khususnya kepala sekolah agar meningkatkan kualitas dan efektivitas gaya kepemimpinan yang digunakan agar kinerja yang dimiliki oleh para guru semakin meningkat,

Bagi peneliti selanjutnya, diharapkan mengkaji lebih dalam mengenai kinerja guru dengan faktor-faktor lain yang tidak dibahas dalam penelitian ini.

\section{DAFTAR PUSTAKA}

Menteri Negara Pendayagunaan Aparatur Negara Dan Reformasi Birokrasi Republik Indonesia. (2009). Peraturan Menteri Negara Pendayagunaan Aparatur Negara dan Reformasi Birokrasi No. 16 Tahun 2009 tentang Jabatan Fungsional Guru dan Angka Kreditnya. 
Mulyasa, E. (2003). Manajemen Berbasis Sekolah. Bandung: PT. Remaja Rosda Karya.

Nogi, H. (2005). Manajemen Publik. Jakarta: Grasindo.

Robbins, S. P., \& Judge, T. A. (2013). Organizational Behavior. (S. Yagan, Ed.) (15th ed.). United States of America: Pearson.

Sedarmayanti. (2001). Sumber Daya Manusia dan Produktivitas. Bandung: Mandar Maju.

Sedarmayanti. (2010). Reformasi Adminitrasi Publik, Reformasi Birokrasi dan Kepemimpinan Masa Depan. Bandung: PT. Reflika Aditama.

Susanto, H. (2012). Faktor-Faktor yang Mempengaruhi Kinerja Guru Sekolah Menengah Kejuruan. Jurnal Pendidikan Vokasi, 2(2), 197-212.

Susanto, H., \& Aisiyah, N. (2010). Analisis Pengaruh Kepemimpinan dan Budaya Kerja dengan Motivasi sebagai Variabel Intervening terhadap Kinerja Karyawan di Kantor Pertanahan Kabupaten Kebumen. Magistra, (74), 15-38.

Suwatno. (2009). Pengaruh Komunikasi dan Iklim Organisasi terhadap Kinerja Guru di SMU Kota Bandung. Jurnal Ilmu Komunikasi, 7(3), 259-277.

Uno, H. B., \& Lamatenggo, N. (2012). Teori Kinerja dan Pengukurannya. (R. Damayanti \& F. Hutari, Eds.). Jakarta: PT. Bumi Aksara.

Wahjono, S. I. (2010). Perilaku Organisasi. Yogyakarta: Graha Ilmu.

Wardana, D. S. (2013). Motivasi Berprestasi dengan Kinerja Guru yang Sudah di Sertifikasi. Jurnal Ilmiah Psikologi Terapan, 1(1), 98-109. 